\title{
Muscarinic Receptor Binding and Muscarinic Receptor-Mediated Inhibition of Adenylate Cyclase in Rat Brain Myelin
}

\author{
J. N. Larocca, ${ }^{1}$ R. W. Ledeen, ${ }^{1,2}$ B. Dvorkin, ${ }^{2}$ and M. H. Makman ${ }^{2,3}$

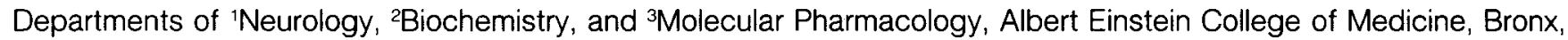 \\ New York 10461
}

High-affinity muscarinic cholinergic receptors were detected in myelin purified from rat brain stem with use of the radioligands ${ }^{3} \mathrm{H}-\mathrm{N}$-methylscopolamine ( $\left.{ }^{3} \mathrm{H}-\mathrm{NMS}\right),{ }^{3} \mathrm{H}$-quinuclidinyl benzilate ( $\left.{ }^{3} \mathrm{H}-\mathrm{QNB}\right)$, and ${ }^{3} \mathrm{H}$-pirenzepine. ${ }^{3} \mathrm{H}-\mathrm{NMS}$ binding was also present in myelin isolated from corpus callosum. In contrast, several other receptor types, including $\alpha_{1}$ - and $\alpha_{2}$ adrenergic receptors, present in the starting brain stem, were not detected in myelin. Based on $B_{\max }$ values from Scatchard analyses, ${ }^{3} \mathrm{H}$-pirenzepine, a putative $M_{1}$ selective ligand, bound to about $25 \%$ of the sites in myelin labeled by ${ }^{3} \mathrm{H}$ NMS, a nonselective ligand that binds to both $M_{1}$ and $M_{2}$ receptor subtypes. Agonist affinity for ${ }^{3} \mathrm{H}-\mathrm{NMS}$ binding sites in myelin was markedly decreased by Gpp(NH)p, indicating that a major portion of these receptors may be linked to a second messenger system via a guanine-nucleotide regulatory protein. Purified myelin also contained adenylate cyclase activity; this activity was stimulated several fold by forskolin and to small but significant extents by prostaglandin $E_{1}$ and the $\beta$-adrenergic agonist isoproterenol. Myelin adenylate cyclase activity was inhibited by carbachol and other muscarinic agonists; this inhibition was blocked by the antagonist atropine. Levels in myelin of muscarinic receptors were 20-25\% and those of forskolin-stimulated adenylate cyclase $10 \%$ of the values for total particulate fraction of whole brain stem. These levels in myelin are appreciably greater than would be predicted on the basis of contamination. Also, additional receptors and adenylate cyclase, added by mixing nonmyelin tissue with whole brain stem, were quantitatively removed during the purification procedure. In conclusion, both $\mathrm{M}_{1}$ and $\mathrm{M}_{2}$ muscarinic receptor subtypes and an adenylate cyclase system linked to at least some of these receptors are present as intrinsic components of myelin. The possibility that some of these muscarinic receptors may be involved in regulation of phosphinositide metabolism and the protein kinase activities of myelin is considered.

The biochemistry of myelin has been studied extensively with respect to events involved in the synthesis of myelin components and, in the subsequent assembly, maintenance and turn-

\footnotetext{
Received Oct. 13, 1986; revised May 26, 1987; accepted May 26, 1987.

This study was supported by PHS Grant NS 16187 (to R.W.L.) and AG 05554 (to M.H.M.). J.N.L. is a recipient of a fellowship from CONICET (Argentina).

Correspondence should be addressed to Dr. Maynard H. Makman, Department of Biochemistry, or Dr. Robert Ledeen, Department of Neurology, Albert Einstein College of Medicine, 1300 Morris Park Avenue, Bronx, NY 10461.

Copyright (C) 1987 Society for Neuroscience $0270-6474 / 87 / 123869-08 \$ 02.00 / 0$
}

over of these components (Benjamins and Smith, 1984). While the origin of the bulk of myelinogenesis and probably some degradative processes occur in the glial cell body, there is mounting evidence that certain metabolic processes and functions take place in the sheath itself. Thus there is a growing list of enzyme activities detected in highly purified myelin (for reviews, see Suzuki, 1980; Norton, 1981; Ledeen, 1984; Norton and Cammer, 1984). While there have not, to our knowledge, been any published reports of receptors in the myelin membrane, the possibility of their presence is indicated by the occurrence of protein kinases (Carnegie et al., 1974; Miyamoto and Kakiuchi, 1974; Steck and Appel, 1974; Murray and Steck, 1986) and protein phosphatase (Miyamoto and Kakiuchi, 1975; McNamara and Appel, 1977) in myelin. Further suggestion of this possibility comes from the high content of polyphosphoinositides in myelin (Eichberg and Dawson, 1965; Norton and Autilio, 1966; Hauser and Eichberg, 1973; Deshmukh et al., 1980), as well as the purported presence of polyphosphoinositide monoand diphosphoesterases (Deshmukh et al., 1982).

We have examined myelin purified from rat brain stem for the presence of certain specific high-affinity receptor sites. We report here that highly purified myelin contains muscarinic cholinergic receptors but not several other classes or types of receptors. The muscarinic receptors were identificd primarily with use of the radioligands ${ }^{3} \mathrm{H}-\mathrm{N}$-methylscopolamine $\left({ }^{3} \mathrm{H}-\mathrm{NMS}\right)$ and ${ }^{3} \mathrm{H}$-quinuclidinyl benzilate $\left({ }^{3} \mathrm{H}-\mathrm{QNB}\right)$. The presence of these receptors in myelin was confirmed by mixing experiments and comparison with unfractionated brain stem. In additional studies, myelin was found to contain adenylate cyclase activity that was inhibited by muscarinic cholinergic agonists. This finding, together with the influence of guanine nucleotides on radioligand binding, indicates that at least a portion of the muscarinic receptors in myelin are coupled to adenylate cyclase. Finally, since a minor but significant subset of muscarinic receptors was capable of binding ${ }^{3} \mathrm{H}$-pirenzepine, a putative $\mathrm{M}_{\mathbf{1}}$-selective ligand (Hammer et al., 1980; Watson et al., 1983, 1986; Luthin and Wolfe, 1984; Evans et al., 1985), it appears that myelin contains not only the $M_{2}$ subtype but also the $M_{1}$ subtype of muscarinic receptor.

\section{Materials and Methods}

Myelin was isolated essentially according to the procedure of Haley et al. (1981) based on the method of Norton and Poduslo (1973). Brain stems were removed from 6- to 8-week-old Sprague-Dawley rats and homogenized $(1.8 \mathrm{gm} / 45 \mathrm{ml})$ in $0.30 \mathrm{M}$ sucrose containing $20 \mathrm{~mm}$ Tris$\mathrm{HCl}$ buffer (pH 7.4) and $2 \mathrm{~mm}$ dithiothreitol (DTT). The same concentrations of buffer and DTT were present in all isolation media used subsequently, including those used for hypotonic shocking and washing. The following steps were employed: (1) The homogenates were layered 
Table 1. Binding of various radioligands to purified myelin and to whole brain-stem membranes

\begin{tabular}{|c|c|c|c|}
\hline \multirow[b]{2}{*}{ Radioligand } & \multicolumn{2}{|c|}{ Specific binding (fmol/mg protein) } & \multirow{2}{*}{$\begin{array}{l}\text { Ratio } \\
\text { (A)/(B) }\end{array}$} \\
\hline & Myelin (A) & Brain stem (B) & \\
\hline${ }^{3} \mathrm{H}-p$-Aminoclonidine (1 $\left.\mathrm{nm}\right)$ & 0 (N.D.) (2) & 18.4 & 0 \\
\hline${ }^{3} \mathrm{H}-\mathrm{WB}-4101(1 \mathrm{~nm})$ & 0 (N.D.) (2) & 44.4 & 0 \\
\hline${ }^{3} \mathrm{H}$-Spiroperidol (0.6 nM) & 0 (N.D.) $(2)$ & 23.5 & 0 \\
\hline${ }^{3} \mathrm{H}$-D-ala-D-leu-enkephalin (7 им) & 0 (N.D.) (2) & 13.7 & 0 \\
\hline${ }^{3} \mathrm{H}-\mathrm{DPAT}(1.2 \mathrm{nM})$ & 0 (N.D.) (1) & 7.1 & 0 \\
\hline${ }^{3} \mathrm{H}-\mathrm{NMS}(0.8 \mathrm{~nm})$ & $40.2+2.2(9)$ & $166 \pm 14(4)$ & 0.24 \\
\hline${ }^{3} \mathrm{H}-\mathrm{NMS}(2.8 \mathrm{nM})$ & $63.1 \pm 6.4(6)$ & $264 \pm 8$ & 0.24 \\
\hline${ }^{3} \mathrm{H}-\mathrm{QNB}(2.5 \mathrm{~nm})$ & $101 \quad(2)$ & 286 & 0.35 \\
\hline${ }^{3} \mathrm{H}$-Pirenzepine (5.0 nM) & $9.5 \pm 2.3(4)$ & $25.0 \pm 1.4(3)$ & 0.38 \\
\hline
\end{tabular}

Myelin was purified from rat brain stem. Values are means \pm SEM, where indicated (number of separate experiments in parentheses).

over $0.83 \mathrm{~m}$ sucrose and centrifuged at $75,000 \times g \times 30 \mathrm{~min}$ and the interphase (myelin) fraction collected; (2) the interphase (myelin) fraction was washed with buffered DT'I, centrifuged at 75,000 $\times g \times 10$ min, and washed twice more with centrifugation at $12,000 \times g \times 10$ min (hypotonic shock and low-speed centrifugation fraction); (3) gradient step (1) was repeated; (4) an additional (third) gradient step was carried out by homogenizing the myelin in $0.83 \mathrm{M}$ sucrose, overlayering the homogenate with $0.30 \mathrm{M}$ sucrose, and then centrifuging at $75,000 \times g \times 30 \mathrm{~min} ;(5)$ the interphase (myelin) fraction was washed by resuspending in buffered DTT and centrifuged at 75,000 $\times g \times 10$ min; (6) the washing step was repeated but with centrifugation at $12,000 \times g \times 10 \mathrm{~min}$; and (7) step (6) was repeated to obtain the final purified myelin fraction. We have demonstrated that this purified preparation contains negligible quantities of several markers for contamination (Wu and Ledeen, 1980; Kunishita and Ledeen, 1984; see also Discussion).

A nonmyelin fraction was obtained at step (1) above by collecting all the material below the myelin interface. The material in suspension was combined with the pellet, diluted with $20 \mathrm{~mm}$ Tris- $\mathrm{HCl}$ buffer to 0.30 $M$ sucrose, and centrifuged at $75,000 \times \mathrm{g}$ for $30 \mathrm{~min}$.

In one mixing experiment, brain stems from 9 rats $(1.6 \mathrm{gm})$ were homogenized together with pooled striata from 18 rats $(0.75 \mathrm{gm})$ in 45 $\mathrm{ml}$ of buffered $0.30 \mathrm{M}$ sucrose, and myelin was isolated as described above. In the other mixing experiment, the nonmyelin fraction (see above) from 12 rats in $45 \mathrm{ml}$ of $0.30 \mathrm{~m}$ sucrose was used to homogenize pooled brain stems from 6 rats as the first step in myelin isolation.

For assays of ${ }^{3} \mathrm{H}-\mathrm{NMS}$ and ${ }^{3} \mathrm{H}-\mathrm{QNB}$ binding, crude homogenates and purified myelin preparations were diluted in $50 \mathrm{~mm}$ Tris $\mathrm{HCl}$ buffer $(\mathrm{pH}$ 7.5) containing $1 \mathrm{mM} \mathrm{MgCl}_{2}$ and centrifuged at $20,000 \times g$ for $10 \mathrm{~min}$. The particulate fraction was resuspended in homogenizing buffer, dispersed with use of a Brinkmann polytron, and centrifuged again. 'The particulate fraction was finally resuspended in the same buffer for assay. Triplicate incubations were carried out with approximately $0.2 \mathrm{mg}$ purified myelin protein in a final volume of $250 \mu \mathrm{l}$. Binding was found to be linear over a myelin protein concentration range of $0.1-0.5 \mathrm{mg}$ per assay tuhe. For competition studies, radioligand concentration was generally $0.6-0.9 \mathrm{~nm}$. For saturation studies, the concentration of ${ }^{3} \mathrm{H}-\mathrm{NMS}$ or ${ }^{3} \mathrm{H}-\mathrm{QNB}$ was varied over a range of 0.01-3.6 nM. Tubes were incubated at $25^{\circ} \mathrm{C}$ for $40 \mathrm{~min}$ and rapidly filtered over Whatman $\mathrm{GF} / \mathrm{B}$ filters followed by four $4 \mathrm{ml}$ rinses of ice-cold $50 \mathrm{~mm}$ Tris- $\mathrm{HCl}$ buffer, pH 7.5. The filters containing membrane precipitates were placed in minivials with liquid scintillation cocktail for counting at a tritium efficiency of $35-41 \%$. Specific binding was defined as the difference between total binding and that found in the presence of $1.0 \mu \mathrm{M}$ atropine (nonspecific binding). For saturation studies with ${ }^{3} \mathrm{H}$-pirenzepine, radioligand concentration was $0.4-16 \mathrm{~nm}$ and the binding reactions were terminated by filtration through Whatman GF/B filters presoaked in $0.05 \%$ aqueous polyethylenimine for $60 \mathrm{~min}$ (Evans et al., 1985); remaining conditions were as described for the other muscarinic radioligands. Nonlinear Scatchard plots were analyzed either by a modification of the computerized procedure of Munson and Rodbard (1980) or by the graphic method of Rosenthal (1967). Binding studies with ${ }^{3} \mathrm{H}-p$ amino-clonidine and ${ }^{3} \mathrm{H}-\mathrm{L}-\left(\left[2^{\prime} 6^{\prime}-\mathrm{CH}_{3} \mathrm{O}\right)_{2}\right]$ phenoxyethylamino $)$ methylbenzo dioxan ( ${ }^{3} \mathrm{H}-\mathrm{WB} 4101$ ) assay were carried out in Tris buffer without other salts present and incubations were at $25^{\circ} \mathrm{C}$ for $30 \mathrm{~min}$. Specific binding for ${ }^{3} \mathrm{H}-p$-amino-clonidine was defined as the difference between total binding and that remaining in the presence of $1 \mu \mathrm{M}$ clonidine; specific binding for ${ }^{3} \mathrm{H}-\mathrm{WB} 4101$ was the difference between total binding and that remaining in the presence of $10 \mu \mathrm{M}(+)$-butaclamol (Leibowitz et al., 1982; Makman and Dvorkin, 1987). Incubations with ${ }^{3} \mathrm{H}$-spiroperidol were at $37^{\circ} \mathrm{C}$ for $20 \mathrm{~min}$ in the presence of $1 \mathrm{mM} \mathrm{MgCl}$, with nonspecific binding defined as that remaining in the presence of $10 \mu \mathrm{M}(+)$-butaclamol (Makman et al., 1982). Incubations with ${ }^{3} \mathrm{H}-\mathrm{D}-$ Ala ${ }^{2}-\mathrm{D}-\mathrm{Leu}^{5}$-enkephalin were in Tris buffer at $25^{\circ} \mathrm{C}$ for $40 \mathrm{~min}$, with nonspecific binding defined as that remaining in the presence of $2 \mu \mathrm{M}$ levorphanol (Walczak et al., 1981; Makman, 1986). Incubations with ${ }^{3} \mathrm{H}$-(R-(+)-8-chloro, 2,3,4,5-tetrahydro-3-methyl-5-phenyl-1H-3-benzazepin-7-ol) $\left({ }^{3} \mathrm{H}-\mathrm{SCH} 23390\right)$ were at $37^{\circ} \mathrm{C}$ for $15 \mathrm{~min}$ in Tris buffer containing $1 \mathrm{mM} \mathrm{MgCl}_{2}$, with nonspecific binding defined as that remaining in the presence of $0.1 \mu \mathrm{M}$ unlabeled SCH 23390 (Makman and Dvorkin, 1986). Incubations with ${ }^{3} \mathbf{H}-8$-hydroxy-2-(di- $n$-propylamino)tetralin ( ${ }^{3} \mathrm{H}-\mathrm{DPAT}$ ) were at $37^{\circ} \mathrm{C}$ for $10 \mathrm{~min}$ in Tris buffer containing $1 \mathrm{mM} \mathrm{MnCl}_{2}$, with nonspecific binding defined as that remaining in the presence of $1 \mu \mathrm{M}$ 5-hydroxytryptamine (Hall et al., 1985).

${ }^{3} \mathrm{H}-\mathrm{NMS}(84.8 \mathrm{Ci} / \mathrm{mmol}),{ }^{3} \mathrm{H}-\mathrm{QNB}(33.1 \mathrm{Ci} / \mathrm{mmol}),{ }^{3} \mathrm{H}$-pirenzepine ( $76 \mathrm{Ci} / \mathrm{mmol}),{ }^{3} \mathrm{H}$-spiroperidol $(30 \mathrm{Ci} / \mathrm{mmol}),{ }^{3} \mathrm{H}$ - $p$-amino-clonidine $\left({ }^{3} \mathrm{H}\right.$ PAC; $57 \mathrm{Ci} / \mathrm{mmol}),{ }^{3} \mathrm{H}-\mathrm{WB} 4101(24.7 \mathrm{Ci} / \mathrm{mmol}),{ }^{3} \mathrm{H}-\mathrm{D}-\mathrm{Ala}^{2}$-D-Leu ${ }^{5}$ enkephalin $(46.9 \mathrm{Ci} / \mathrm{mmol})$, and ${ }^{3} \mathrm{H}$-DPAT $(157 \mathrm{Ci} / \mathrm{mmol})$ were from New England Nuclear. $\left[N\right.$-methyl- $\left.{ }^{3} \mathrm{H}\right] \mathrm{SCH} 23390(80 \mathrm{Ci} / \mathrm{mmol})$ and unlabeled SCH 23390 were kindly provided by Drs. L.C. Iorio and A. Barnett of the Schering-Plough Corporation.

For adenylate cyclase assay, brain tissue or purified myelin was homogenized by hand in an all-glass homogenizer in $2 \mathrm{~mm}$ Tris-maleate buffer (pH 7.4) with $0.8 \mathrm{~mm}$ EDTA. The homogenates were centrifuged and the particulate fraction resuspended in the homogenizing buffer for assay. The final incubation medium, which was in a volume of $100 \mu \mathrm{l}$, contained $80 \mathrm{~mm}$ Tris-maleate buffer ( $\mathrm{pH} 7.4$ ), $10 \mathrm{~mm}$ theophylline, 2 mM $\mathrm{MgSO}_{4}, 0.5 \mathrm{~mm} \mathrm{Na}_{2}$ ATP, $50 \mu \mathrm{M}$ GTP, 0.2 mм EDTA, $20 \mu \mathrm{M}$ ouabain, $2 \mathrm{~mm}$ phosphoenolpyruvate, $10 \mu \mathrm{g} / \mathrm{ml}$ pyruvate kinase, and $10-20 \mu \mathrm{g}$ myelin protein per assay tube. Incubation was at $30^{\circ} \mathrm{C}$ for 15 min. Cyclic AMP formed during the incubation was measured by a competitive binding assay. Other details, including the competitive binding assay for measurement of the cyclic AMP formed during the incubation were as described previously (Longshore and Makman, 1981; Rosenfeld and Makman, 1981). Protein was determined by the method of Lowry et al. (1951).

\section{Results}

In view of the high concentration of phosphoinositides and related enzymes in myelin (see introduction), and the well-established muscarinic cholinergic receptor-mediated regulation of phosphoinositide metabolism, we first examined myelin for the presence of muscarinic receptors (Michell et al., 1976; Berridge and Irvine, 1984; Brown and Masters, 1984; Nishizuka, 1984; Fisher, 1986). As shown in Table 1, muscarinic cholin- 

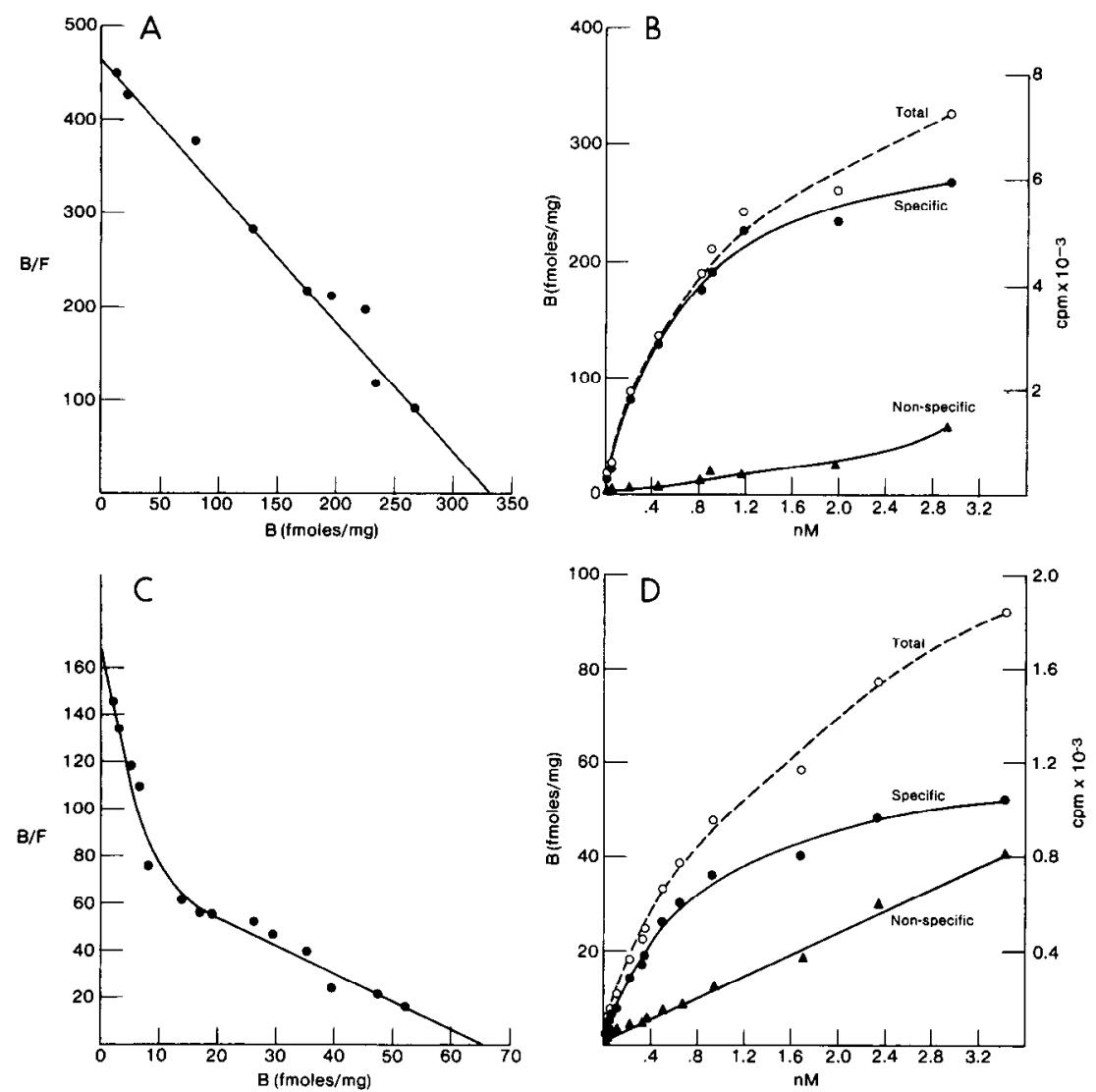

Figure 1. Saturation of ${ }^{3} \mathrm{H}-\mathrm{NMS}$ binding sites in brain stem ( $A$ and $B$ ) and in myelin purified from brain stem $(C$ and $D) . A$ and $C$ are Scatchard plots for saturation data shown respectively in $B$ and $D(O--\infty$, total binding; $\longrightarrow \longrightarrow$, specific binding; $\Delta-\boldsymbol{\Lambda}$, nonspecific binding). The data represent mean values for the separate experiments summarized in Table 2. For brain stem $(A), B_{\max }$ is $325 \mathrm{fmol} /$ $\mathrm{mg}$ protein and $K_{D}, 0.74 \mathrm{nM}$. For myelin (C), $B_{\max }$ is $67 \mathrm{fmol} / \mathrm{mg}$ protein (total). Best-fit computer analysis yields 2 components, the first with $B_{\max }$ of $3 \mathrm{fmol} / \mathrm{mg}$ protein and $K_{D}$ of 0.028 $\mathrm{nM}$, and the second with a $B_{\max }$ of 64 $\mathrm{fmol} / \mathrm{mg}$ protein and a $K_{D}$ of $1.03 \mathrm{~nm}$. ergic binding, measured with ${ }^{3} \mathrm{H}-\mathrm{NMS},{ }^{3} \mathrm{H}-\mathrm{QNB}$, or ${ }^{3} \mathrm{H}-$ pirenzepine, could be detected in purified myelin as well as in the crude particulate (membrane) fraction from whole brain stem. Muscarinic binding in myelin was considerable, representing $24-38 \%$ of that found in brain stem (Table 1). In contrast, receptor binding sites for several other radioligands were present in whole brain stem but were not detected in myelin purified from that tissue (Table 1). These included ${ }^{3} \mathrm{H}$-PAC $\left(\alpha_{2}\right.$-adrenergic), ${ }^{3} \mathrm{H}$-WB 4101 ( $\alpha_{1}$-adrenergic), ${ }^{3} \mathrm{H}$-spiroperidol [serotonergic $\left(5-\mathrm{HT}_{2}\right)$ and dopaminergic $\left(\mathrm{D}_{2}\right)$ ], ${ }^{3} \mathrm{H}$-DPAT [serotonergic $\left.\left(5-\mathrm{HT}_{\mathrm{la}}\right)\right]$, and ${ }^{3} \mathrm{H}-\mathrm{D}-\mathrm{Ala}-\mathrm{D}-\mathrm{Leu}-\mathrm{enkephalin}$ (opioid) receptor binding sites.

Saturation studies were carried out for ${ }^{3} \mathrm{H}-\mathrm{NMS}$ and ${ }^{3} \mathrm{H}-\mathrm{pi}-$ renzepine binding sites in brain stem, in the initial nonmyelin fraction obtained at step 1 of the purification procedure and in purified myelin. $B_{\max }$ and $K_{D}$ values are summarized in Table 2. Also, composite data from the separate experiments for ${ }^{3} \mathrm{H}$ NMS binding in brain stem and purified myelin, as well as Scatchard plots of those data, are illustrated in Figure 1. Binding was monophasic for both ${ }^{3} \mathrm{H}-\mathrm{NMS}$ and ${ }^{3} \mathrm{H}$-pirenzepine in brain stem and in the nonmyelin fraction; a single binding component was also found for ${ }^{3} \mathrm{H}$-pirenzepine. However, the Scatchard plot of ${ }^{3} \mathrm{H}-\mathrm{NMS}$ binding in myelin was curvilinear (Fig. 1), with computer analysis indicating the presence of a small number $\left(B_{\max } 3.5 \mathrm{fmol} / \mathrm{mg}\right.$ protein) of very high affinity sites $\left(K_{D}, 0.03\right.$ $\mathrm{nM})$ in addition to the major component $\left(B_{\max }, 69 \mathrm{fmol} / \mathrm{mg}\right.$ protein; $K_{D}, 0.75 \mathrm{nM}$ ) that was equivalent to the single component found in brain stem $\left(B_{\max }, 311 \mathrm{fmol} / \mathrm{mg}\right.$ protein; $K_{D}$, $0.54 \mathrm{nM}$ ). $B_{\max }$ for ${ }^{3} \mathrm{H}-\mathrm{NMS}$ in myelin was $23 \%$ of that for ${ }^{3} \mathrm{H}$ -
NMS in brain stem. $B_{\max }$ for ${ }^{3} \mathrm{H}$-pirenzepine in myelin was $26 \%$ of that for ${ }^{3} \mathrm{H}$-pirenzepine in brain stem and $26 \%$ of that for ${ }^{3} \mathrm{H}-\mathrm{NMS}$ in myelin. It has been previously estimated that approximately $30 \%$ of white matter protein is myelin protein (W.T. Norton, personal communication). Based on that estimate, $B_{\max }$ values for ${ }^{3} \mathrm{H}-\mathrm{NMS}$ and ${ }^{3} \mathrm{H}$-pirenzepine in whole brain are close to those calculated from the values for the separate myelin and

Table 2. Summary of $B_{\max }$ and $K_{D}$ values for radioligand binding to muscarinic receptors in brain stem, purified myelin, and the nonmyelin fraction derived from brain stem

\begin{tabular}{|c|c|c|}
\hline $\begin{array}{l}\text { Ligand and } \\
\text { preparation }\end{array}$ & $\begin{array}{l}B_{\max } \\
\text { (fmol/mg protein) }\end{array}$ & $K_{D}(\mathrm{nM})$ \\
\hline \multicolumn{3}{|l|}{${ }^{3} \mathrm{H}-\mathrm{NMS}$} \\
\hline \multicolumn{3}{|l|}{ Myelin } \\
\hline Total & $73 \pm 11(6)$ & \\
\hline (I) & $3.5 \pm 1.1(4)$ & $0.030 \pm 0.011(4)$ \\
\hline (II) & $69 \pm 5$ & $0.75 \pm 0.08$ \\
\hline Nonmyelin & 376 & 1.2 \\
\hline Brain stem & $311 \pm 18$ & $0.54 \pm 0.09$ \\
\hline \multicolumn{3}{|c|}{${ }^{3} \mathrm{H}$-Pirenzepine } \\
\hline Myelin & $18.9 \pm 4.2(3)$ & $4.6 \pm 0.9$ \\
\hline Nonmyelin & $99.2 \quad$ (2) & 10.0 \\
\hline Brain stem & $75.7 \pm 1.3(3)$ & $6.8 \pm 0.9$ \\
\hline
\end{tabular}

Values are means \pm SEM obtained from Scatchard analyses of separate saturation experiments (number of experiments in parentheses). Nonmyelin refers to the material remaining after removal of the initial brain stem myelin fraction at step 1 of the purification procedure. 
Figure 2. Competition for ${ }^{3} \mathrm{H}-\mathrm{NMS}$ binding sites in myelin purified from brain stem. Values are means of 3 separate experiments. Symbols:

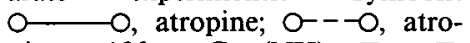
pine $+100 \mu \mathrm{M}$ Gpp(NH)p; $\square-\square$, scopolamine; $\mathbf{\Delta}-\mathbf{A}$, oxotremorine; $\Delta---\mathbf{\Delta}$, oxotremorine $+100 \mu \mathrm{M}$ $\mathrm{Gpp}(\mathrm{NH}) \mathrm{p} ; \longrightarrow$, carbachol; 0 - - , carbachol $+100 \mu \mathrm{M}$ $\mathrm{Gpp}(\mathrm{NH}) \mathrm{p} ; \times \longrightarrow \times, \mathrm{ACh}$.

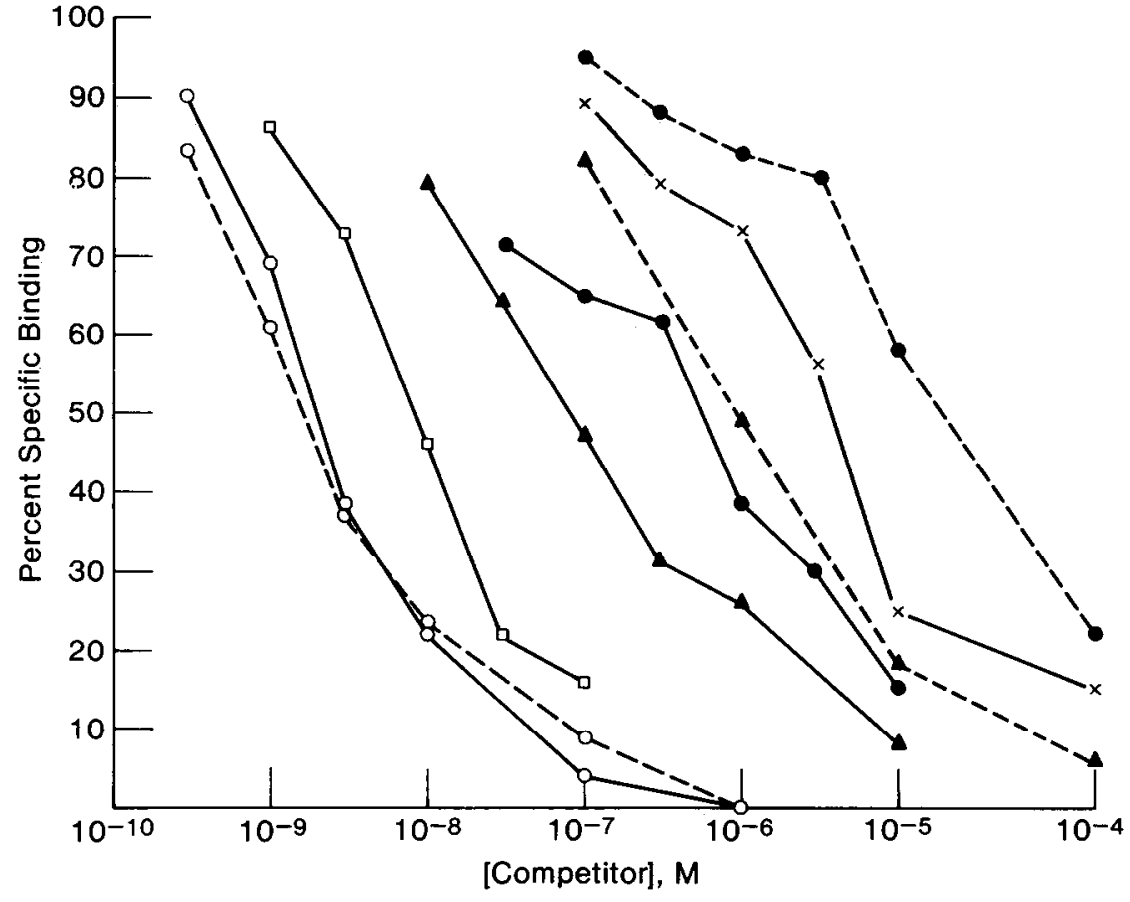

the non-myelin fraction shown in Table 2 (calculated $B_{\max }$ values are $185 \mathrm{fmol} / \mathrm{mg}$ protein for ${ }^{3} \mathrm{H}-\mathrm{NMS}$ and $75 \mathrm{fmol} / \mathrm{mg}$ protein for ${ }^{3} \mathrm{H}$-pirenzepine). In a separate experiment, myelin purified from corpus callosum by the same procedure used for brain stem was examined and also found to contain ${ }^{3} \mathrm{H}$-NMS binding. Scatchard analysis of the saturation data indicated a single binding component, with $B_{\max }$ of $45 \mathrm{fmol} / \mathrm{mg}$ protein and $K_{D}$ of 0.23 nM.

Competition studies were carried out to ascertain the relative affinities of various substances for ${ }^{3} \mathrm{H}$-NMS binding sites in myelin purified from brain stem (Fig. 2). The muscarinic antagonists atropine and scopolamine exhibited higher potency than did the agonists oxotremorine, carbachol, and $\mathrm{ACh} ; K_{i}$ values and Hill coefficients calculated from these data are shown in Table 3. Potencies of these substances are similar to those

Table 3. Competition for ${ }^{3} \mathrm{H}-\mathrm{NMS}$ binding sites in purified rat brain-stem myelin by muscarinic agents

\begin{tabular}{lcl} 
Agent & $\begin{array}{l}K_{i} \\
(\mathrm{nM})\end{array}$ & $\begin{array}{l}\text { Hill } \\
\text { coeffi- } \\
\text { cient }\end{array}$ \\
\hline Atropine & $1.1 \pm 0.2$ & 0.99 \\
Atropine + Gpp(NH)p $(100 \mu \mathrm{M})$ & $0.8 \pm 0.2$ & 0.94 \\
Scopolamine & $5.2 \pm 0.3$ & 0.92 \\
Oxotremorine & $30 \pm 6$ & 0.62 \\
Oxotremorine $+\mathrm{Gpp}(\mathrm{NH}) \mathrm{p}(100 \mu \mathrm{M})$ & $780 \pm 30$ & 0.67 \\
Carbachol & $224 \pm 42$ & 0.50 \\
Carbachol $+\mathrm{Gpp}(\mathrm{NH}) \mathrm{p}(100 \mu \mathrm{M})$ & $8900 \pm 210$ & 0.63 \\
ACh & $2200 \pm 130$ & 0.55
\end{tabular}

$\overline{\text { Values are means } \pm \text { SEM of } 3 \text { separate experiments for each agent, each exper- }}$ iment involving triplicate determinations at each concentration studied. $K_{i}$ was calculated from the relationship $K_{i}=1 \mathrm{C}_{50} /\left[1+\left({ }^{3} \mathrm{H}-\mathrm{NMS}\right) / K q D\right] . \mathrm{IC}_{50}$, the concentration for $50 \%$ inhibition of specific binding was determined from the Hill plot. ${ }^{3} \mathrm{H}$-HMS concentration averaged $0.8 \mathrm{~nm}$. The $K_{D}$ for ${ }^{3} \mathrm{II}-\mathrm{NMS}$ (Table 2 , Fig. 1) was $0.75 \mathrm{~nm}$. reported for other muscarinic receptor preparations, with the exception of $\mathrm{ACh}$, which is less potent here than in certain other preparations (Hammer et al., 1980; Watson et al., 1983, 1986; Lee and El-Fakahany, 1985; Anthony and Aronstam, 1986). The relatively high affinity of carbachol is consistent with binding of this agonist primarily to high agonist affinity sites (Ehlert et al., 1981; Anthony and Aronstam, 1986). Hill coefficients for the agonists were lower than those obtained for the antagonists. Addition of $100 \mu \mathrm{M} \mathrm{Gpp}(\mathrm{NH}) \mathrm{p}$ to the assay system caused a considerable decrease in the affinity of the agonists oxotremorine and carbachol for receptor sites but did not change the affinity of the antagonist atropine (Fig. 2, Table 3). GTP also decreased the affinity of carbachol, whereas ATP had no effect (data not shown). Thus, guanine nucleotides selectively influence the interaction of agonists with these receptor binding sites in myelin.

The presence of similar levels of muscarinic binding sites in myelin purified from 2 different brain regions, brain stem and corpus callosum, as well as the absence of several other types of binding sites in purified myelin indicated that muscarinic receptors are an intrinsic component of myelin membrane (see also Discussion) or at the very least are closely and selectively associated with myelin. In order to further assess the possibility of contamination of the purified myelin, binding sites were measured at different steps of the purification procedure. Also, purification was carried out starting with an artificial mixture of brain stem plus striatum. With this latter procedure, brain stem was enriched not only with ${ }^{3} \mathrm{H}-\mathrm{NMS}$ binding sites but also with a high content of $D_{1}$ receptor sites (measured with ${ }^{3} \mathrm{H}-\mathrm{SCH}$ 23390) that are normally not present. As shown in Table 4, even when the brain-stem preparation is contaminated with additional ${ }^{3} \mathrm{H}-\mathrm{NMS}$ binding sites and with ${ }^{3} \mathrm{H}-\mathrm{SCH}-23390$ binding sites, the added sites are removed by step 3 (second gradient) of the purification procedure, and ${ }^{3} \mathrm{H}$-NMS binding is essentially the same at steps 3,4 , and 7 (final purified myelin). These data also indicate that there is no inhibitory factor present in crude brain stem since binding values for the crude mixture of brain 
Table 4. Removal of striatal dopamine $\mathrm{D}_{1}\left({ }^{3} \mathrm{H}-\mathrm{SCH}-23390\right)$ and of contaminating striatal muscarinic ( ${ }^{3} \mathrm{H}-\mathrm{NMS}$ ) binding sites during purification of myelin from a mixture of brain stem and striatal tissue

\begin{tabular}{llc} 
& \multicolumn{2}{c}{$\begin{array}{l}\text { Specific binding } \\
\text { (fmol/mg protein) }\end{array}$} \\
\cline { 2 - 3 } & \multicolumn{2}{c}{$\begin{array}{c}{ }^{3} \mathrm{H}- \\
\text { SCH- }\end{array}$} \\
Preparation (Purification step) & ${ }^{3}$ H-NMS & 23390 \\
\hline Whole brain stem & 149 & 3.2 \\
Striatum & 422 & 302 \\
Whole brain stem + striatum (mixture) & 263 & 139 \\
Mixture purification fraction & & \\
$\quad$ First gradient (step 1) & 175 & 50.8 \\
Hypotonic shock + low-speed & & \\
$\quad$ centrifiguation (step 2) & 82.2 & 8.4 \\
$\quad$ Second gradient (step 3) & 16.7 & 0.7 \\
$\quad$ Third gradient (step 4) & 20.9 & 0 \\
$\quad$ Final fraction (step 7) & 21.9 & 0.7 \\
Myelin (purified from brain stem) & 25.5 & 2.3
\end{tabular}

Details for the mixing experiment and the purification steps indicated are described under Materials and Methods. Triplicate determinations were carried out for each condition and preparation studied.

stem plus striatum are essentially as predicted from the separate values.

The influence of guanine nucleotides on agonist binding to ${ }^{3} \mathrm{H}-\mathrm{NMS}$ receptor sites in myelin (Table 3, Fig. 2) suggested the possibility that at least some of these receptors might be coupled to a second messenger system through a guanine nucleotide regulatory protein. Purified myelin was found to contain adenylate cyclase activity stimulated several fold by the diterpine activator forskolin (Seamon et al., 1981; Gilman, 1984), with smaller stimulations produced by isoproterenol and prostaglandin $E_{t}$ (Table 5). Activity in the presence of forskolin was considerable, constituting approximately $10 \%$ of that found in wholc brain stem. The concentration dependence for stimulation by forskolin is shown in Figure 3.

Adenylate cyclase activity of purified myelin was found to be inhibited by the muscarinic agonist carbachol (Tables 5 and 6). This inhibition appeared to be receptor mediated, since the inhibition was markedly attenuated in the presence of atropine (Table 6). The relative potencies of muscarinic agonists for inhibitions of myelin adenylate cyclase are also consistent with a receptor-mediated interaction. As shown in Figure 4 , myelin adenylate cyclase, assayed in the presence of forskolin, is inhibited in a dose-dependent manner by muscarinic agonists,

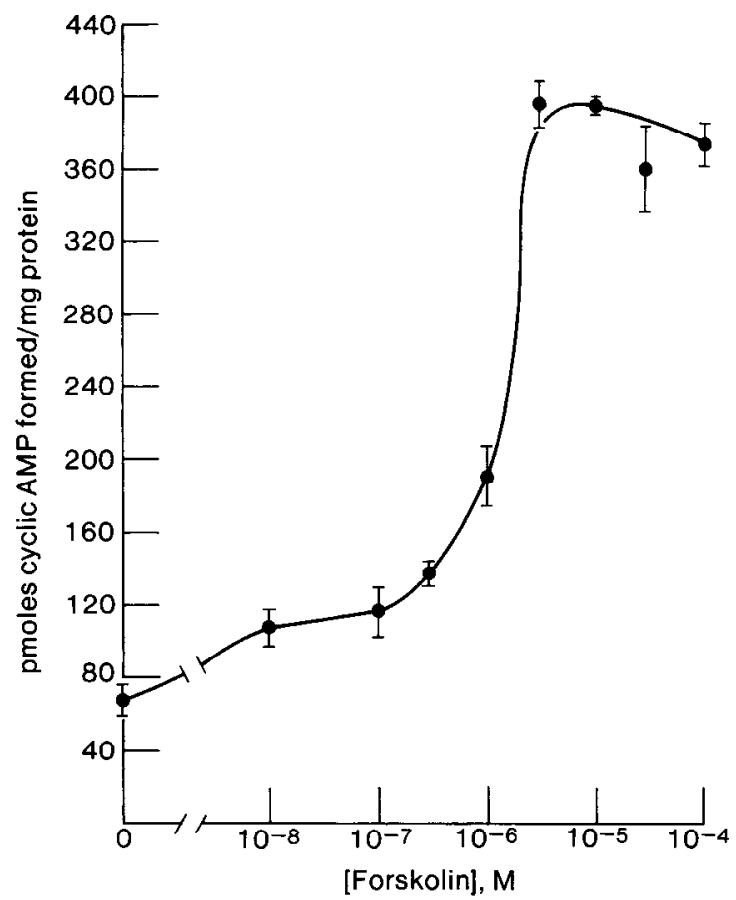

Figure 3. Forskolin-stimulated adenylate cyclase activity of myelin purified from brain stem. Values are means \pm SEM of 3-5 separate experiments.

with an order of potency of oxotremorine $>$ carbachol $>$ pilocarpine.

In order to assess the possible contamination of myelin with nonmyelin adenylate cyclase, myelin was purified from a mixture of brain stem plus striatum (as described above for ${ }^{3} \mathrm{H}-$ NMS binding); myelin was also purified from brain stem enriched with additional nonmyelin membranes. As shown in Table 7, valucs for basal and forskolin-stimulated adenylate cyclase activity in the final purified myelin fraction were not influenced by contaminations of the original brain stem homogenate with striatal tissue or with additional nonmyelin fraction from brain stem. Also, the highly active striatal dopaminestimulated adenylate cyclase present in the mixture of brain stem and striatum was quantitatively removed during the purification procedure.

\section{Discussion}

The present study has demonstrated for the first time that in association with highly purified rat brain myelin there are pres-

Table 5. Adenylate cyclase activity of whole brain stem and of myelin purified from brain stem

\begin{tabular}{|c|c|c|c|}
\hline \multirow[b]{2}{*}{ Additions } & \multicolumn{2}{|c|}{$\begin{array}{l}\text { Adenylate cyclase activity } \\
\text { (pmol cyclic AMP formed/mg protein) }\end{array}$} & \multirow{2}{*}{$\begin{array}{l}\text { Ratio } \\
\text { (A)/(B) }\end{array}$} \\
\hline & Myelin (A) & Brain stem (B) & \\
\hline None (basal) & $72.6(8)$ & $1520(5)$ & 0.05 \\
\hline Prostaglandin $E_{1}$ & 113 (6) $[+55 \pm 12 \%]$ & $1940(3)[+28 \pm 8 \%]$ & 0.06 \\
\hline Isoproterenol & $106 \quad(5)[+46 \pm 11 \%]$ & $2210(3)[+46 \pm 15 \%]$ & 0.05 \\
\hline Forskolin & $401 \quad(8)$ & $3850(5)$ & 0.10 \\
\hline Forskolin + carbachol & $304 \quad$ (8) $[-24 \pm 6 \%]$ & $2141(5)[-19 \pm 4 \%]$ & 0.10 \\
\hline
\end{tabular}

All additions were present at $10 \mu \mathrm{M}$. Number of separate experiments are in parentheses. Values for percentage

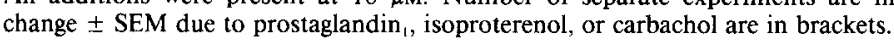


Table 6. Influence of carbachol and atropine on adenylate cyclase activity of myelin purified from rat brain stem

\begin{tabular}{lc} 
& $\begin{array}{l}\text { Adenylate cyclase } \\
\text { activity (pmol } \\
\text { cyclic AMP/mg } \\
\text { protein) }\end{array}$ \\
Additions & 81 \\
\hline None (basal) & $59(-27 \pm 6 \%)$ \\
Carbachol $(10 \mu \mathrm{M})$ & 488 \\
Forskolin $(10 \mu \mathrm{M})$ & $255(-43 \pm 6 \%)$ \\
Forskolin $(10 \mu \mathrm{M})+$ carbachol $(10 \mu \mathrm{M})$ & $421(-6 \pm 2 \%)$ \\
Forskolin $(10 \mu \mathrm{M})+$ carbachol + & atropine $(1 \mu \mathrm{M})$
\end{tabular}

$\overline{V a l u e s}$ are means of 3 separate experiments. Values for percentage change \pm SEM due to carbachol are in parentheses.

ent muscarinic cholinergic receptor binding sites and an adenylate cyclase activity stimulated by isoproterenol, prostaglandin $E_{1}$, and forskolin that is inhibited by a cholinergic receptor mechanism. Values for total number of muscarinic receptor binding sites as well as for the relative proportion of those sites labeled by ${ }^{3} \mathrm{H}-\mathrm{QNB},{ }^{3} \mathrm{H}-\mathrm{NMS}$, and ${ }^{3} \mathrm{H}$-pirenzepine in whole brain stem reported here are similar to values reported previously for pons-medulla (Luthin and Wolfe, 1984; Evans et al., 1985; Lee and El-Fakahany, 1985). The curvilinear Scatchard plot for ${ }^{3} \mathrm{H}-\mathrm{NMS}$ binding in purified myelin, reported here (Fig. $1)$, indicated the possible presence of a very high affinity component $\left(K_{D}, 0.03 \mathrm{nM}\right)$ in addition to the major component with a $K_{D}$ of $0.75 \mathrm{nM}$. A binding component for ${ }^{3} \mathrm{H}-\mathrm{NMS}$ similar to the minor component in myelin has not been reported previously for ${ }^{3} \mathrm{H}-\mathrm{NMS}$ binding in CNS tissue (Watson et al., 1986). The minor component represented only $5 \%$ of the total ${ }^{3} \mathrm{H}-\mathrm{NMS}$ binding in myelin, and its significance is not known; also the minor component was not evident when ${ }^{3} \mathrm{H}-\mathrm{QNB}$ was used as radioligand.

The ratio of putative $M_{1}$ receptor sites (labeled by ${ }^{3} \mathrm{H}$-pirenzepine) to $\mathrm{M}_{1}$ plus $\mathrm{M}_{2}$ sites (labeled nonselectively by ${ }^{3} \mathrm{H}-\mathrm{QNB}$ or ${ }^{3} \mathrm{H}-\mathrm{NMS}$ ) in pons-medulla and cerebellum was previously

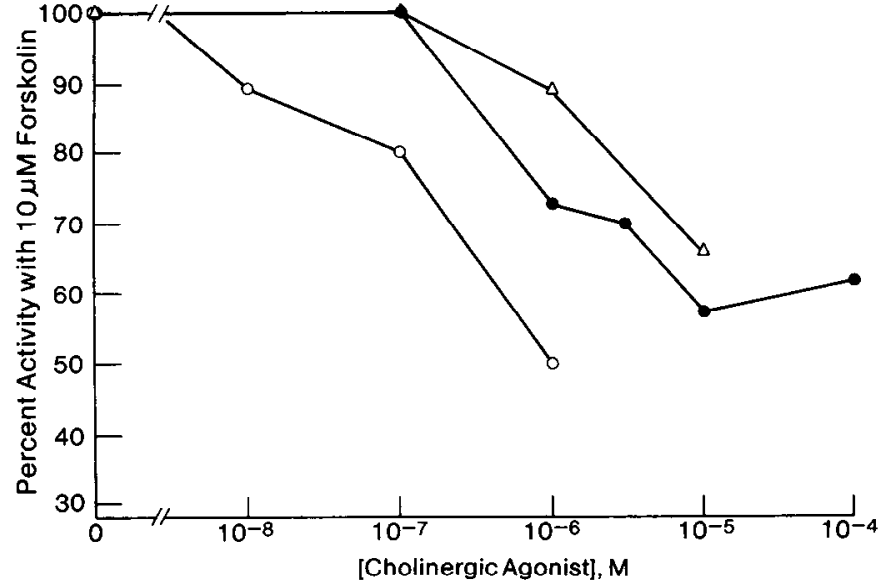

Figure 4. Inhibition by muscarinic agonists of forskolin-stimulated adenylate cyclase activity of myelin purified from brain stem. Values are means of 3 separate experiments. Symbols: $\mathrm{O}_{-} \mathrm{O}$, oxotremorine; $\bullet \longrightarrow$, carbachol; $\triangle \longrightarrow$, pilocarpine.

found to be less than that ratio in cerebral cortex or in certain other CNS regions (Watson et al., 1983; Luthin and Wolfe, 1984; Lin et al., 1986). The relative proportion of $M_{1}$ and $M_{2}$ receptor sites also differs in peripheral tissues (Watson et al., 1983, 1986; Luthin and Wolfe, 1984). In the present study, ${ }^{3} \mathrm{H}$-pirenzepine labeled $24-26 \%$ of the sites labeled by ${ }^{3} \mathrm{H}-\mathrm{NMS}$ both in purified myelin and in whole brain stem. Thus, in association with purified myelin there is present predominantly the $\mathbf{M}_{2}$ subtype of muscarinic receptor, but the $M_{1}$ subtype is also present. While it has been proposed that the $M_{1}$ receptor mediates stimulation of phosphoinositide metabolism and the $\mathrm{M}_{2}$ receptor is involved primarily in inhibition of adenylate cyclase, this distinction has been questioned (Brown et al., 1985; Akiyama et al., 1986; Fisher, 1986; Harden ct al., 1986; Watson et al., 1986; see also below).

Based on the present studies, the adenylate cyclase system associated with purified myelin includes not only the guanine

Table 7. Adenylate cyclase activity of myelin purified from brain stem contaminated with striatal tissue or enriched with the nonmyelin fraction of brain stem

\begin{tabular}{lccc} 
& \multicolumn{3}{c}{$\begin{array}{l}\text { Adenylate cyclase activity } \\
\text { (pmol cyclic AMP formed/mg protein) }\end{array}$} \\
\cline { 2 - 4 } Preparation & & $\begin{array}{l}\text { Forskolin } \\
(10 \mu \mathrm{M})\end{array}$ & $\begin{array}{l}\text { Dopa- } \\
\text { mine } \\
(10 \mu \mathrm{M})\end{array}$ \\
\hline Experiment I & Basal & & \\
Brain stem & & & 1440 \\
Striatum & 1180 & 3580 & 2360 \\
Brain stem + striatum (mixture) & 1190 & 25,000 & 2240 \\
Myelin purified from brain stem & 930 & 7660 & 54 \\
Myelin purified from mixture & 71 & 430 & 92 \\
Experiment II & 68 & 500 & \\
Initial nonmyelin fraction & & & \\
Myelin purified from brain stem & 1900 & 3360 & \\
Myclin purificd from cnriched preparation & 84 & 589 &
\end{tabular}

In experiment I, homogenates of brain stem and striatum were mixed. In experiment II, brain stem homogenate was enriched with additional nonmyelin fraction from brain stem. Other details for the mixing experiment are given in Materials and Methods. Triplicate assay incubations were carried out for each condition and preparation studied. 
nucleotide regulatory protein, $G_{s}$, involved in forskolin- and receptor mediated-stimulation, but also the regulatory proteins, $\mathrm{G}_{\mathrm{i}}$, required for muscarinic receptor-mediated inhibition (Gilman, 1984). In a previous study, evidence was presented for the presence in myelin of the $G_{s}$ protein, but little or no adenylate cyclase activity could be detected (Enomoto and Asakawa, 1983). The reason for the different findings in that and in our study is not clear. Possible factors include the presence of DTT during the purification procedure as well as the different assay conditions and the use of forskolin in our study. Our studies of myelinassociated adenylate cyclase focuscd primarily on the characterization of muscarinic agonist-inhibited adenylate cyclase, assayed in the presence of forskolin. The presence of receptors mediating stimulation of adenylate cyclase was suggested by the relatively small but significant stimulatory effects of the $\beta$-adrenergic agonist isoproterenol and of prostaglandin $E_{1}$ on activity in myelin. Also, in preliminary experiments $\beta$-adrenergic receptor binding in purified myelin was detected using ${ }^{125} \mathrm{I}$-cyanopindolol as radioligand. However, further studies will be required to determine whether $\beta$-adrenergic or other receptors selectively mediate stimulation of adenylate cyclase associated with myelin. Also it remains to be determined whether the same adenylate cyclase in myelin is regulated by stimulatory and by inhibitory receptors, e.g., whether isoproterenol-stimulated activity is inhibited by carbachol.

A well-known positive marker for myelin is the myelin-specific enzyme $2^{\prime}, 3^{\prime}$-cyclic nucleotide- $3^{\prime}$-phosphohydrolase (Norton and Cammer, 1984). We previously reported that myelin isolated by the standard Norton-Poduslo procedure in our laboratory contains high levels of this phosphohydrolase as well as the expected proportions of myelin-specific proteins (Haley et al., 1981). We have also demonstrated that such myelin, subjected to additional purification steps as employed here, contains negligible quantities of NADPII-cytochrome $c$ reductase and lactate dehydrogenase (Kunishita and Ledeen, 1984) and 3 other negative markers for contamination (Wu and Ledeen, 1980). On the other hand, myelin is known to contain a large and growing number of enzyme activities that are nonspecific in that they are also present in other brain constituents or compartments (Suzuki, 1980; Norton and Cammer, 1984). These nonspecific myelin-localized activities may be present in myelin with specific activity varying from less than $10 \%$ to more than equal that of the unfractionated homogenate. Muscarinic cholinergic receptors appear to be present in myelin at a concentration of about $20-25 \%$ that present in the starting resuspended particulate (crude, total membrane) fraction. Forskolin-stimulated and carbachol-inhibited adenylate cyclase were found to be present in myelin at a concentration about $10 \%$ that of the starting particulate fraction. These values are in the range of those found for a number of myelin-associated enzyme activities and constituents. Also, they are clearly far greater than the estimated level of contamination by axonal, microsomal, or other subcellular fractions using the purification procedure employed here (Haley et al., 1981; Kunishita and Ledeen, 1984). The upper limit of such contamination was estimated in the latter studies as $0.6-1.2 \%$ of myelin protein. If neuronal (e.g., axonal) contaminants were to contain all the activity found in myelin, these membranes would have a $B_{\max }$ value for ${ }^{3} \mathrm{H}-\mathrm{NMS}$ of approximately $6000-12,000 \mathrm{fmol} / \mathrm{mg}$ protein; such high density has not been reported for any brain region or membrane. Similar considerations apply to ${ }^{3} \mathrm{H}$-pirenzepine binding and the adenylate cyclase activity of myelin.
The mixing experiments reported in the present study also confirm that nonmyelin (including synaptosomal) markers, such as dopamine $D_{1}$ receptors, dopamine-stimulated adenylate cyclase, and even nonmyelin ${ }^{3} \mathrm{H}-\mathrm{NMS}$ binding sites and forskolinstimulated adenylate cyclase, are efficiently removed from the brain stem myelin fraction during purification. The selective presence of the muscarinic receptor system in myelin is indicated by the absence in myelin of several other receptor types, including the relatively widely distributed $\alpha_{2}$ - and $\alpha_{1}$-noradrenergic receptors. The evidence thus points to $M_{1}$ and $M_{2}$ muscarinic receptors and the adenylate cyclase system as integral components of the myelin membrane.

The ability of ${ }^{3} \mathrm{H}$-pirenzepine to bind to some of the muscarinic sites associated with myelin indicates that $M_{1}$ as well as $\mathrm{M}_{2}$ receptors are present, raising the possibility that these different receptor populations may subserve different functions. One possibility, rendered likely by ongoing studies in our laboratory, is muscarinic regulation of phosphoinositide metabolism in myelin. The fact that cholinergic stimulation of brain stem slices resulted in breakdown of myelin phosphoinositides (Larocca et al., 1988) further strengthens the argument that myelin itself contains the muscarinic receptors. Similar preliminary findings have been reported by Kahn and Morell (1986), although that study did not address the question of myelin receptors per se. Myelin has recently been shown to contain protein kinase C-like enzymatic activity and myelin basic proteins can scrvc as substrates for this enzyme (Murray and Steck, 1986). Cholinergic stimulation of phosphoinositide breakdown might provide the initial signal for activation of this protein kinase (Nishizuka, 1984).

The adenylate cyclase system associated with myelin and the coupling of muscarinic receptors to that system as described in this paper thus provide another mode for cholinergic regulation in myelin. In addition to protein kinase $C$, myelin has been reported to contain cyclic AMP-dependent protein kinase activity (protein kinase A) (Miyamoto and Kakiuchi, 1974); one possibly important endogenous substrate for that enzyme in myelin is a Wolfgram protein whose phosphorylation has been shown to be catalyzed by protein kinase A (Bradbury et al., 1984). In summary, our results indicate the presence in myelin of muscarinic receptors of both the $M_{1}$ and $M_{2}$ subtypes and an adenylate cyclase system regulated by at least a portion of these cholinergic receptors. Studies are currently in progress to further elucidate the properties and role of these systems in CNS myelin as well as their possible presence in peripheral nerves.

\section{References}

Akiyama, K., T. W. Vickroy, M. Watson, W. R. Roeske, T. D. Reisine, T. L. Smith, and H. I. Yamamura (1986) Muscarinic cholinergic ligand hinding to intact mouse pituitary tumor cells (AtT-20/D 1616) coupling with two biochemical effectors: Adenylate cyclase and phosphatidylinositol turnover. J. Pharmacol. Exp. Ther. 236: 653661 .

Anthony, B. L., and R. S. Aronstam (1986) Effect of $\mathrm{pH}$ on muscarinic acetylcholine receptors from rat brainstem. J. Neurochem. 46: 556561 .

Benjamins, J. A., and M. E. Smith (1984) Metabolism of myelin. In Myelin, 2nd ed., P. Morell, ed., pp. 225-258, Plenum, New York.

Berridge, M. J., and R. F. Irvine (1984) Inositol triphosphate, a novel second messenger in cellular signal transduction. Nature 312: 315320.

Bradbury, J. M., R. S. Campbell, and R. J. Thompson (1984) Endogenous cyclic AMP-stimulated phosphorylation of a Wolfgram protein component in rabbit central-nervous system myelin. Biochem. J. 221. 351-359. 
Brown, J. H., and S. B. Masters (1984) Muscarinic regulation of phosphatidylinositol turnover and cyclic nucleotide metabolism. Fed. Proc. 43: 2613-2614.

Brown, J. H., D. Goldstein, and S. B. Masters (1985) The putative $M_{1}$ muscarinic receptor does not regulate phosphoinositide hydrolysis-studies with pirenzepine and Mc N-A343 in chick heart and astrocytoma cells. Mol. Pharmacol. 27: 525-531.

Carnegie, P. R., P. R. Dunkley, B. E. Kemp, and A. W. Murray (1974) Phosphorylation of selected serine and threonine residues in myelin basic protein by endogenous and exogenous protein kinases. Nature 249: 147-150.

Deshmukh, D. S., S. Kuizon, W. D. Bear, and H. Brockerhoff (1980) Distribution of phosphoinositides among subfractions of rat brain myelin. Lipids 15: 14-18.

Deshmukh, D. S., S. Kuizon, W. D. Bear, and H. Brockerhoff (1982) Polyphosphoinositide mono- and diphosphoesterases of three subfractions of rat brain myelin. Neurochem. Res. 7: 617-626.

Ehlert, F. J., W. R. Roeske, and H. I. Yamamura (1981) Regulation of muscarinic receptor binding. Adv. Behav. Biol. 25: 609-619.

Eichberg, J., and R. M. C. Dawson (1965) Polyphosphoinositides in myelin. Biochem. J. 96: 644-650.

Enomoto, K., and T. Asakawa (1983) Evidence for the presence of a GTP-dependent regulatory component of adenylate cyclase in myelin from rat brain. J. Neurochem. 40: 434-439.

Evans, R. A., M. Watson, H. I. Yamamura, and W. R. Roeske (1985) Differential ontogeny of putative $M_{1}$ and $M_{2}$ muscarinic receptor binding sites in the murine cerebral cortex and heart. J. Pharmacol. Exp. Ther. 235: 612-618.

Fisher, S. K. (1986) Inositol lipids and signal transduction at CNS muscarinic receptors. Trends Pharmacol. Sci. (Suppl.) 7: 61-65.

Gilman, A. G. (1984) G proteins and dual control of adenylate cyclase. Cell 36: 577-579.

Haley, J. E., F. G. Samuels, and R. W. Ledeen (1981) Study of myelin purity in relation to axonal contaminants. Cell Mol. Neurobiol. 1: 175-187.

Hall, M. D., S. E. Mestikaway, M. B. Emerit, L. Pichat, M. Hamon, and $\mathrm{H}$. Gozlan (1985) $\left[{ }^{3} \mathrm{H}\right]-8-\mathrm{Hydroxy}-1-(\mathrm{di}-n$-propylamino) tetralin binding to pre- and post-synaptic 5-hydroxytryptamine sites in various regions of the rat brain. J. Neurochem. 44: 1685-1696.

Hammer, R., C. P. Berrie, N. J. M. Birdsall, A. S. V. Burgen, and E. C. Hulme (1980) Pirenzepine distinguishes between different subclasses of muscarinic receptors. Nature 283: 90-92.

Harden, T. K., I. L. Tanner, M. W. Martin, N. Nakahata, A. R. Hughes, J. R. Hepler, T. Evans, S. B. Masters, and J. H. Brown (1986) Characteristics of two biochemical responses to stimulation of muscarinic cholinergic receptors. Trends Pharmacol. Sci. (Suppl.) 7: 14-18.

Hauser, G., and J. Eichberg (1973) The subcellular distribution of polyphosphoinositides in myelinated and unmyelinated rat brain. Biochim. Biophys. Acta 326: 210-223.

Kahn, D., and P. Morell (1986) Cholinergic stimulation of phosphoinositide metabolism in rat brain myelin. Trans. Am. Soc. Neurochem. 17: 315 .

Kunishita, T., and R. W. Leeden (1984) Phospholipid biosynthesis in myelin: Presence of CTP: Phosphoethanolamine cytidylyltransferase in purified myelin of rat brain. J. Neurochem. 42: 326-333.

Larocca, J. M., A. Cervone, and R. W. Ledeen (1988) Stimulation of phosphoinositide hydrolysis in myelin by muscarinic agonist and potassium. Brain Res. (in press).

Ledeen, R. W. (1984) Lipid-metabolizing enzymes of myelin and their relation to the axon. J. Lipid Res. 25: 1548-1554.

I ee, J.-H., and E. E. El-Fakahany (1985) Heterogeneity of binding of muscarinic receptor antagonists in rat brain homogenates. J. Pharmacol. Exp. Ther. 233: 707-714.

Leibowitz, S. F., M. Jhanwar-Uniyal, B. Dvorkin, and M. H. Makman (1982) Distribution of $\alpha$-adrenergic, $\beta$-adrenergic and dopaminergic receptors in discrete hypothalamic areas of rat. Brain Res. 233: 97114.

Lin, S.-C., K. C. Olson, H. Okazaki, and E. Richelson (1986) Studies on muscarinic binding sites in human brain identified with [ $\left.{ }^{3} \mathrm{H}\right]$ pirenzepine. J. Neurochem. 46: 274-279.

Longshore, M., and M. H. Makman (1981) Stimulation of retinal adenylate cyclase by vasoactive intestinal peptide (VIP). Eur. J. Pharmacol. 70: 237-240.

Lowry, O. H., N. J. Rosebrough, A. L. Farr, and R. J. Ranoull (1951) Protein measurement with the Folin phenol reagent. J. Biol. Chem. 193: 265-275.
Luthin, G. R., and B. B. Wolfe (1984) Comparison of $\left[{ }^{3} \mathrm{H}\right]$ pirenzepine and $\left[{ }^{3} \mathrm{H}\right]$ quinuclidinylbenzilate binding to muscarinic cholinergic receptors in rat brain. J. Pharmacol. Exp. Ther. 228: 648-655.

Makman, M. H. (1986) Interactions of monoamines with opioids and related peptides. In Handbook of Comparative Opioid and Related Neuropeptide Mechanisms, Vol. 1, G. B. Stefano, ed., pp. 263-271, CRC Press, Boca Raton, FL.

Makman, M. II., and B. Dvorkin (1986) Binding sites for ${ }^{3} \mathrm{H}-\mathrm{SCH}$ 23390 in retina: Properties and possible relationship to dopamine $\mathrm{D}_{1}$ receptors mediating stimulation of adenylate cyclase. Mol. Brain Res. 1: $261-270$.

Makman, M. H., B. Dvorkin, and P. N. Klein (1982) Sodium ion modulates $D_{2}$ receptor characteristics of dopamine agonist and antagonist binding sites in striatum and retina. Proc. Natl. Acad. Sci. USA 79: 4212-4216.

McNamara, J. O., and S. H. Appel (1977) Myelin basic protein phosphatase activity in rat brain. J. Neurochem. 29:27-35.

Michell, R. H., S. S. Jofferji, and L. M. Jones (1976) Receptor occupancy dose-response curve suggests that phosphatidyl-inositol breakdown may be intrinsic to the mechanism of the muscarinic cholinergic receptor. FEBS Lett. 69: 1-5.

Miyamoto, E., and S. Kakiuchi (1974) In vitro and in vivo phosphorylation of myelin basic protein by exogenous and endogenous adenosine $3^{\prime}: 5^{\prime}$-monophosphate-dependent protein kinases in brain. J. Biol. Chem. 249: 2769-2777.

Miyamoto, E., and S. Kakiuchi (1975) Phosphoprotein phosphatases for myelin basic protein in myelin and cytosol fractions of brain. Biochim. Biophys. Acta 384: 458-465.

Munson, P. J., and D. Rodbard (1980) LIGAND: A versatile computerized approach for characterization of ligand-binding systems. Anal. Biočhem. 107: 220-239.

Murray, N., and A. J. Steck (1986) Activation of myelin protein kinase by diacylglycerol and $4 \beta$-phorbol 12-myristate 13-acetate. J. Neurochem. 46: $1655-1657$.

Nishizuka, Y. (1984) Turnover of inositol phospholipids and signal transduction. Science 225: 1365-1370.

Norton, W. T. (1981) Biochemistry of myelin. In Demyelinating Disease: Basic and Clinical Electrophysiology, S. G. Waxman and J. M. Ritchie, eds., pp. 93-121, Raven Press, New York.

Norton, W. T., and L. A. Autilio (1966) The lipid composition of purified bovine brain myelin. J. Neurochem. 13: 213-222.

Norton, W. T., and W. Cammer (1984) Isolation and characterization of myelin. In Myelin, P. Morell, ed., pp. 147-195, Plenum Press, New York.

Norton, W. T., and S. Poduslo (1973) Myelination in rat brain: Method of myelin isolation. J. Neurochem. 21: 749-751.

Rosenfeld, M. R., and M. H. Makman (1981) The interaction of lisuride, an ergot derivative, with serotonergic and dopaminergic receptors in rabbit brain. J. Pharmacol. Exp. Ther. 216: 526-531.

Rosenthal, H. E. (1967) A graphic method for the determination and presentation of binding parameters in a complex system. Anal. Biochem. 21: 525-532.

Seamon, K. B., W. Padgett, and J. W. Daly (1981) Forskolin: Unique diterpine activator of adenylate cyclase in membranes and in intact cells. Proc. Natl. Acad. Sci. USA 78: 3363-3367.

Steck, A. J., and S. H. Appel (1974) Phosphorylation of myelin basic protein. J. Biol. Chem. 249: 5416-5420.

Suzuki, K. (1980) Myelin-associated enzymes. In Neurological Mutations Affecting Myelination, N. Baumann, ed., pp. 333-347, Elsevier/North-Holland Biomedical Press, Amsterdam.

Walczak, S. A., M. H. Makman, and E. L. Gardner (1981) Acetylmethadol metabolites influence opiate receptors and adenylate cyclase in amygdala. Eur. J. Pharmacol. 72: 343-349.

Watson, M., H. I. Yamamura, and W. R. Roeske (1983) A unique regulatory profile and regional distribution of $\left[{ }^{3} \mathrm{H}\right]$ pirenzepine binding in the rat provide evidence for distinct $\mathrm{M}_{1}$ and $\mathrm{M}_{2}$ muscarinic receptor subtypes. Life Sci. 32: 3001-3011.

Watson, M., W. R. Roeske, T. W. Vickroy, T. L. Smith, K. Akiyama, K. Golya, S. P. Duckles, M. Serra, A. Adem, A. Nordberg, D. R. Gehlert, J. K. Wamsley, and H. I. Yamamura (1986) Biochemical and functional basis of putative muscarinic receptor subtypes and its implications. Trends Pharmacol. Sci. (Suppl.) 7: 46-55.

$\mathrm{Wu}$, P.-S., and R. W. Ledeen (1980) Evidence for the presence of CDP-ethanolamine: 1,2-diacyl-sn-glycerol ethanolaminephosphotransferase in rat central nervous system myelin. J. Neurochem. 35: $659-666$ 